\title{
Prototipe Tempat Sampah Elektronik Bersuara Berbasis Mikrokontroler ATMega328P dan Decoder VS1011
}

\author{
Anwar Mujadin $^{1}$, Dwi Astharini ${ }^{2}$ \\ ${ }^{1,2}$ Program Studi Teknik Elektro, Fakultas Sains dan Teknologi, Universitas Al Azhar Indonesia, \\ Komplek Masjid Agung Al Azhar Kebayotan Baru, Jakarta Selatan, Kode Pos 12110 \\ Penulis untuk Korespondensi/E-mail: amujadin@uai.ac.id
}

\begin{abstract}
Abstrak - Perilaku membuang sampah sembarangan tidak pernah lepas dari pengaruh lingkungan sekitar. Saat ini, dalam menangggapi masalah buang sampah sembarangan sudah menjadi kebiasaan dimasyarakat yang biasa karena semua orang melakukannya. Merubah prilaku orang sangatlah tidak mudah perlu cara yang luar biasa. Pada penelitian ini telah dirancang bangun sebuah divais yang menyuguhkan beraneka ragam suara "aneh" yang menyebabkan si pembuang sampah selalu ingin melempar sampahnya pada divais ini. Prototipe menggunakan mikrokontroler ATMega328P dan decoder VS1011 sebagai pemutar suara dalam format MP3. Sistem elektronik menggunakan catu daya operasi baterai 12V, 5V dan 3.3V. Tulisan ini akan menjelaskan teknis optocoupler, power regulator dan karakteristik baterai.
\end{abstract}

Kata Kunci - Tempat Sampah Elektronik, Teknis Optocoupler, Power Regulator dan Karakteristik Baterai

Abstract - Behavior of littering is never out of the environment. Currently, in dealing with the problem of littering has become a habit in the ordinary community because everyone is doing it. Changing people's behavior is not easy to need a great way. In this research has been designed to build a device that presents a variety of "weird" sound that causes the garbage disposal always wants to throw the garbage on this device. The prototype uses an ATMega328P microcontroller and VS1011 decoder as a sound player in MP3 format. Electronic systems use battery operation power supply $12 \mathrm{~V}, 5 \mathrm{~V}$ and $3.3 \mathrm{~V}$. This paper will explain the technical optocoupler, power regulator and battery characteristics.

Keywords - Electronic Bin, Technical Optacoupler, Power Regulator, and Battery Characteristics

\section{PENDAHULUAN}

$\mathrm{K}^{\mathrm{s}}$ esadaran masyarakatnya akan kebersihan masih sangat rendah, masyarakat menganggap membuang sampah sembarangan adalah suatu hal yang wajar dan tidak berdosa, sehingga tidak ada satu pun yang memperingatkan atau menegur pembuang sampah. Terlebih bila tidak disediakannya tempat sampah yang memadai. Pengaruh lingkungan merupakan suatu faktor besar di dalam munculnya suatu perilaku. Perilaku membuang sampah sembarangan tidak pernah lepas dari pengaruh lingkungan sekitar. Saat ini, dalam menangggapi masalah pembuangan sampah sembarangan sudah menjadi kbiasaan dimasyarakat yang biasa karena semua orang melakukannya [1].

Seharusnya masalah yang yang paling utama adalah merubah prilaku dulu baru menyelesaikan masalah sampahnya. Kebiasaan ini tidak mengenal status sosial atau pun tingkat pendidikan.

Merubah prilaku orang sangatlah tidak mudah perlu cara yang luar biasa. Penyuluhan akan pentingnya menjaga kebersihan, disertai dampak negatif yang dihasilkan karena membuang sampah sembarangan, sampai dengan penetapan sanksi walaupun hal ini terasa berat namun hal ini penting untuk dilaksanakan untuk kebaikan bersama[2]. 
Pada tulisan ini akan dibahas mengenai rangkaian perangkat keras (divais) yang mendukung prototipe tempat sampah bersuara ini. Divais mampu menarik perhatian pembuang sampah. Divais ini akan menyuguhkan alunan suara 3D saat si pembuang sampah tepat memasukan sampah pada prototipe ini. Divais akan menyuguhkan beraneka ragam suara "aneh" yang menyebabkan si pembuang sampah selalu ingin melempar sampahnya pada divais ini.

\section{TINJAUAN PUSTAKA}

\section{Music Shield V.2}

Music shield adalah sebuah ekspansi board untuk board mikrokontroler Arduino UNO R3. Board ini mampu memainkan suara dalam format MP3, WMA, WAV, AAC dan MIDI. Music shield adalah sebuah audio encoderdecoder berbasis chip VSC1053B, bersama dengan mikrokontroler (embedd) chip ini mampu memainkan dan merekam suara, yang datanya dapat dibaca atau disimpan dalam kartu memori SD Card melalui komunikasi data SPI. Penambahan multi fungsi switch pada board ini menjadikan pengguna seperti memiliki sebuah pemutar suara portable. Pada Gambar 1 diperlihatkan board dari Music Shield V2.0 [3].

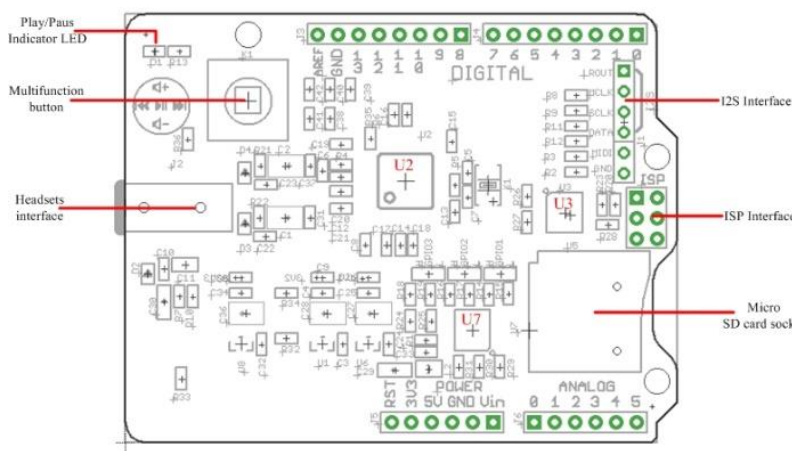

Gambar 1. Music Shield V.2 [3].

Spesifikasi teknis dari Music shield V.2 adalah sebagai berikut:

Multifunction button: Change volume and select songs. Play/Pause indicator LED (GREEN) : Blinks while playing. Headsets interface: It can drive $16 \mathrm{ohm}$ or $32 \mathrm{ohm}$ earphone and could serve as a external audio input port. Micro SD card: can be FAT16 or
FAT32, The maximum size SD card you can use is 2GB. U2: VS1053B IC, Ogg Vorbis /MP3/AAC/WMA/FLAC/MIDI audio codec. U3,U7: 74VHC125 IC, Quad Buffer. I2S: for digital audio input/output. ISP interface: for bringing SPI port when using with Mega series products. Pins usage on Arduino Pins Used for Play Control: D4 - receiving signal from switch for Next Song function

\section{METODE PENELITIAN}

Reverse engineering music shield V.2 dan Arduino UNO R3. Rancang bangun hardware terutama pada sistem komunikasi input-output $\mathrm{I} / \mathrm{O} 5 \mathrm{~V}$ ke 3.3V. Mempelajari optocoupler sebagai bridge $5 \mathrm{~V}$ ke $12 \mathrm{~V}$, sebagai ripple noise reduction dan sistem proteksi. Uji coba dan analisa prilaku responden terhadap device.

\section{RANCANG BANGUN PERANGKAT KERAS ANALISA DAN UJI COBA}

\section{Blok Diagram Prototipe}

Adapun diagram blok dari "Pembuatan Prototipe Tempat Sampah Elektronik Berbasis Mikrokontroler Atmega328P dan Decoder VS1011" diperlihatkan pada Gambar 2 berikut:

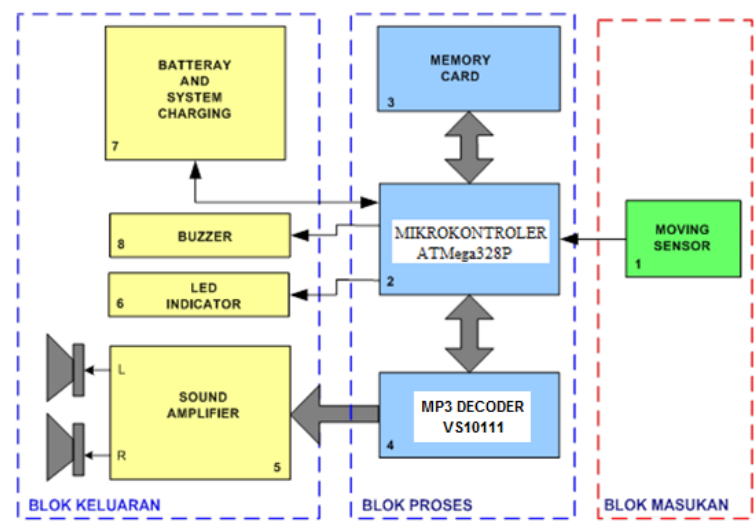

Gambar 2. Blok Diagram prototipe

\section{Rancangan circuit Prototipe}

Rancang bangun pemutar music MP3 diperlihatkan pada Gambar 3. 


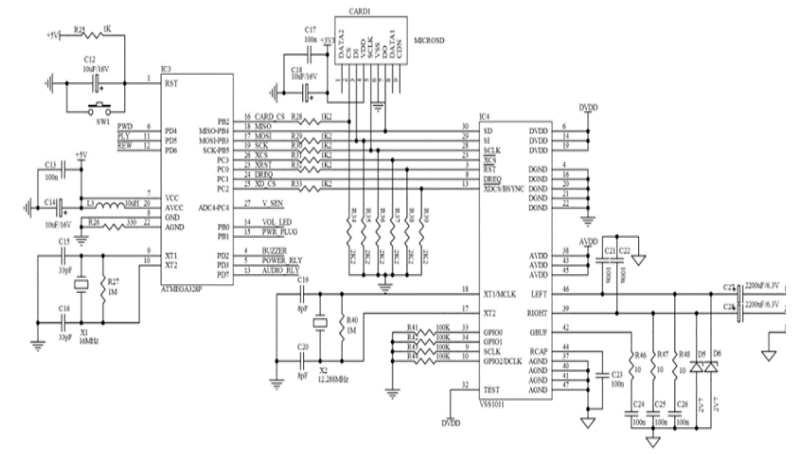

Gambar 3. Rangkaian pemutar music MP3

Pada Gambar 3 adalah rangkaian reverse engineering dari board music shield V.2. Microcontroler ATmega328P (IC3) bekerja pada tegangan catu sebesar $5 \mathrm{~V}$ sedangkan kartu micro SD (CARD1) dan IC decoder VSS1011 (IC4) bekerja pada tegangan $3.3 \mathrm{~V}$. Untuk menghindari kerusakan baik pada CARD1 maupun pada IC4 maka diperlukan rangkaian pembagi tegangan. Pembagi tegangan akan menurunkan tegangan dari $5 \mathrm{~V}$ menjadi $3.3 \mathrm{~V}$. Gambar 3 terlihat resistor pull up (RU) R28R33 bernilai masing-masing sebesar $2 \mathrm{~K} 2 \Omega$ dan resistor pull down (RD) dari R34-39 bernilai masing-masing $1 \mathrm{~K} 2 \Omega$. Vin adalah tegangan kekuaran dari IC3 dan Vout adalah tegangan yang masuk ke CARD1 dan IC4 maka didapat formulasi pembagai tegangan berikut:

Vout $=\frac{\mathrm{RD}}{\mathrm{RD}+\mathrm{RU}} \cdot \mathrm{Vin}=\frac{2.2 \mathrm{~K}}{2.2 \mathrm{~K}+1.2 \mathrm{~K}} \cdot 5 \mathrm{~V}=3.24 \mathrm{~V}$

Tegangan keluaran pada CARD1 maupun pada IC4 dapat langsung dihubungkan ke IC3 tanpa menggunakan pembagi tegangan lagi, karena tegangan $3.3 \mathrm{~V}$ masih dianggap logika ' 1 ' oleh mikrokontroler (IC3) sebagai taraf transistortransistor logic (TTL).

Pada Gambar 4 diperlihatkan rangkaian optoisolator untuk menghidupkan (a) audio power dan (b) pengisi baterai

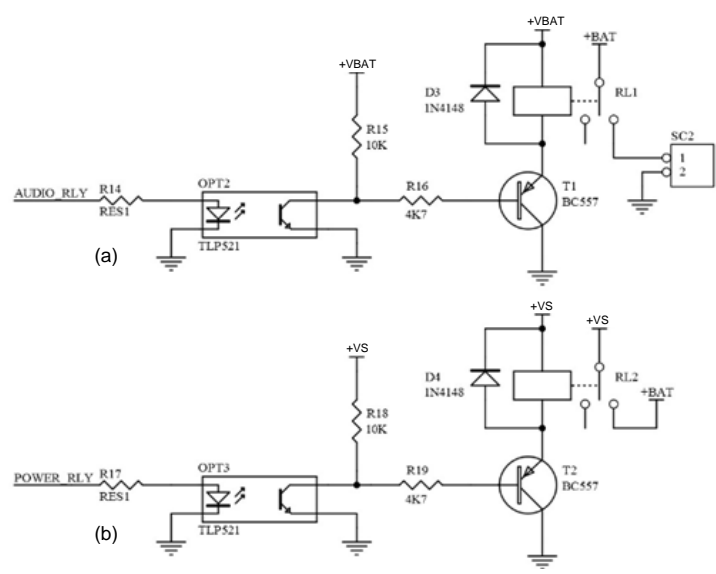

Gambar 4. Rangkaian optoisolator untuk menghidupkan (a) audio power dan

(b) pengisi baterai

Pada Gambar 4 (a) diperlihatkan optocoupler audio power switch. Rangkaian ini untuk menghidupkan catu daya pada rangkaian elektronika audio. Optocoupler power switch dikendalikan oleh tegangan berlogika ' 1 ' melewati pin AUDIO_RLY. Pada Gambar 5 diperlihatkan perluasan dari Gambar 4 (a) sebagai optocoupler audio power switch.

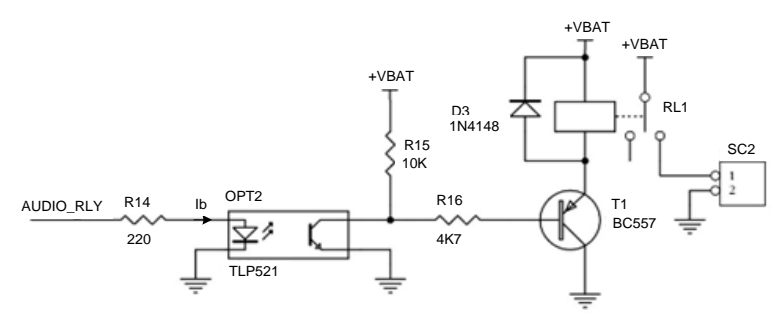

Gambar 5. Optocoupler power switch audio

Optocoupler (OPT2) digunakan sebagai dinding pembatas antara tegangan $5 \mathrm{~V}$ dengan $12 \mathrm{~V}$ (+BAT). Tegangan forward bias ( $\mathrm{Vfb})$ pada LED OPT2 adalah sebesar $2 \mathrm{~V}$, bila tegangan kontrol (Vk) berlogika logika ' 1 ' (5V) dari IC3, maka besaran arus bias (Ib) yang diberikan oleh microcontroler lewat pin AUDIO_RLY pada LED OPT2 adalah sebesar: 


$$
\mathrm{Ib}=\frac{\mathrm{Vk}-\mathrm{Vfb}}{\mathrm{R} 14}=\frac{5-2}{220}=13.6 \mathrm{~mA}
$$

Karena batas ambang port keluaran IC3 adalah sebesar $20 \mathrm{~mA}$, maka besaran $\mathrm{Ib}=13.6 \mathrm{~mA}$ masih bisa ditolerir tanpa merusak pin keluaran IC3. Pada saat LED pada OPT2 diberikan tegangan bias (Ib), maka LED OPT2 akan meningkatkan arus basis pada fototransistor OPT2. Tegangan pada kolektor-emitor fototransistor OPT2 semula $12 \mathrm{~V}$ (cut off) menjadi sekitar $0.2 \mathrm{~V}$ (saturasi).

Pada Gambar 6 diperlihatkan rangkaian pengganti Thevenin saat pin kolektor fototransistor OPT2 bernilai $0.2 \mathrm{~V}$.

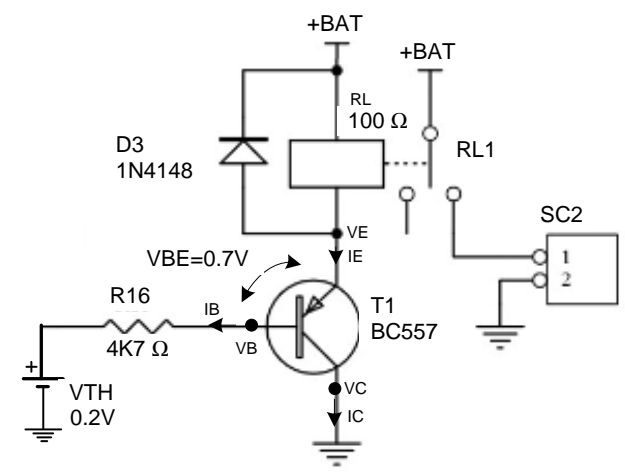

Gambar 6. Rangkaian pengganti Thevenin saatpin kolektor fototransistor OPT2 bernilai $0.2 \mathrm{~V}$.

Dari Gambar 6, saat diberikan tegangan 0.2V transistor T1 akan saturasi dimana nilai $\mathrm{VEC}=$ $0,2 \mathrm{~V}$ maka nilai besaran tegangan VE dapat diketahui yaitu sebesar :

$$
\begin{aligned}
& \mathrm{VEC}=\mathrm{VE}-\mathrm{VC} \\
& \mathrm{VE}=\mathrm{VEC}+\mathrm{VC} ; \mathrm{VC}=0 \mathrm{~V} \text { (ground) } \\
& \mathrm{VE}=0.2 \mathrm{~V}
\end{aligned}
$$

Arus emitor IE dapat dicari dengan formulasi:

$$
\mathrm{IE}=\frac{+\mathrm{BAT}-\mathrm{VE}}{\mathrm{RL}}=\frac{12-0.2}{100}=118 \mathrm{~mA}
$$

Besaran tegangan Basis (VB) dapat dicari sebagai:

$$
\begin{aligned}
\mathrm{VBE} & =\mathrm{VB}-\mathrm{VE} ; \mathrm{VBE}=0.7 \mathrm{~V} \\
\mathrm{VB} & =\mathrm{VBE}+\mathrm{VE}=0.7+0.2 \\
\mathrm{VB} & =0.9 \mathrm{~V}
\end{aligned}
$$

Besaran arus Basis (IB) dapat dicari sebagai:

$$
\mathrm{IB}=\frac{\mathrm{VB}-\mathrm{VTH}}{\mathrm{R} 16}=\frac{0.9-0.2}{4 \mathrm{k} 7}=149 \mathrm{uA}=0.149 \mathrm{~mA}
$$

OPT2 berfungsi sebagai noise reducer dan protektor mikrokontroler. Saat RL1 ON-OFF terjadi ripple tegangan di +VBAT, tegangan $5 \mathrm{~V}$ (VCC) tidak akan terganggu oleh keadaan RL1 ini. Bila terjadi kerusakan transistor (T1) akibat overload, tegangan +VBAT $(+12 \mathrm{~V})$ tidak akan bercampur dengan $\mathrm{VCC}(+5 \mathrm{~V})$ stelah di pasang OPT2 ini.

Pada Gambar 7 diperlihatkan rangkaian elektronika power charging dan $5 \mathrm{~V}$ power regulator.

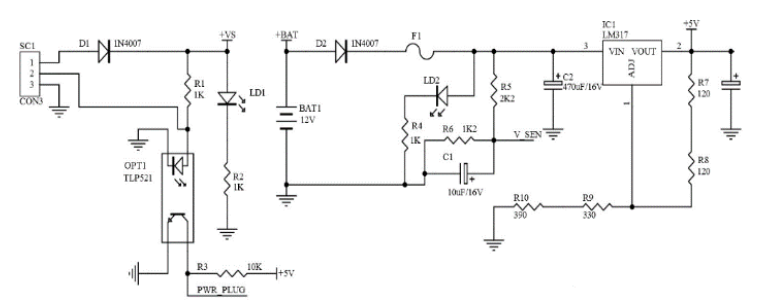

Gambar 7. Rangkaian elektronika power charging dan $5 \mathrm{~V}$ power regulator.

Bila power supply charging ( $\mathrm{VCH})$ sebesar $+15 \mathrm{~V}$ melewati dioda D1 dengan tegangan forward (VD) dikoneksikan ke power plug SC1, maka LED pada OPT1 akan menyala dengan tegangan foward (Vf) sebesar $2 \mathrm{~V}$ arus yang masuk ke led adalah sebesar:

$$
\mathrm{Ib}=\frac{(\mathrm{VCH}-\mathrm{VD})-\mathrm{Vf}}{\mathrm{R} 1}=\frac{(15-0.7)-2}{1000}=12.3 \mathrm{~mA}
$$

Saat LED menyala, Basis pada fototransistor OPT1 akan mendapatkan arus bias sehingga akan saturasi, tegangan pada kolektor OPT1 semula memiliki tegangan 5V (logika ' 1 ') akan berubah menjadi $0.2 \mathrm{~V}$ (logika ' 0 '). Microkontroler (IC3) dapat mendeteksi perubahan logika tersebut melalui pin PWR_PLUG, artinya mikrokontroler dapat mendeteksi apakah power charger sedang terkoneksi atau tidak. LED (LD1) adalah sebagai monitoring bahwa bila LD1 ini menyala menandakan bahwa power plug charging sedang terkoneksi. Arus yang masuk pada LD1 sebesar: 
$\mathrm{Ib}=\frac{(\mathrm{VCH}-\mathrm{VD})-\mathrm{Vf}}{\mathrm{R} 2}=\frac{(15-0.7)-2}{1000}=12.3 \mathrm{~mA}$

Tegangan +VS dapat dihubungkan untuk mengisi baterai (BAT2) menggunakan rangkaian Gambar 4(b).

Mikrokontroler mampu mengidentifikasi tegangan baterai melaui pin V_SEN. R5 dan R6 membentuk pembagi tegangan sebesar:

$\mathrm{V}_{\mathrm{SEN}}=\frac{\mathrm{R} 6}{\mathrm{R} 5+\mathrm{R} 6} \cdot \mathrm{VBAT}=\frac{1.2}{1.2 \mathrm{~K}+2 \cdot 2 \mathrm{~K}} \cdot 12 \mathrm{~V}=4 \cdot 23 \mathrm{~V}$

Dengan faktor pembagi sebesar:

$$
\frac{1.2 \mathrm{~K}}{1.2 \mathrm{~K}+2.2 \mathrm{~K}}=0.353
$$

Artinya bila tegangan baterai penuh (12V) dibaca oleh mikrokontroler adalah sebesar 4.23 V. Pada Tabel 1 diperlihatkan hubungan korelasi antara tegangan baterai terhadap kapasitas daya baterai (\%) juga terhadap tegangan terbaca oleh mikokontroler .

Pada Gambar 8. Diperlihatkan hasil rancang bangun dari prototipe tempat sampah bersuara (a)

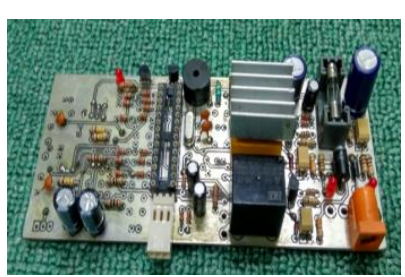

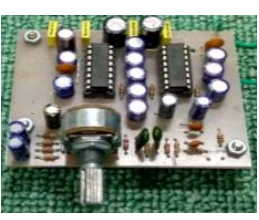

(b)

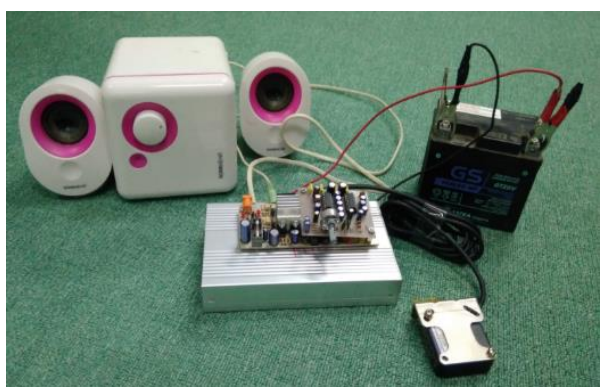

(c)

Gambar 8. Rancang bangun prototipe (a) main board (b) board audio (c) prototipe lengkap

Pada Gambar 9 diperlihatkan proses perakitan dan pengujian mekanikal tempat sampah elektronik bersuara.

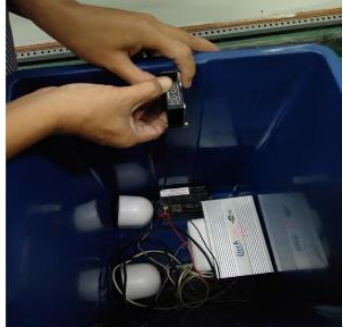

(a)

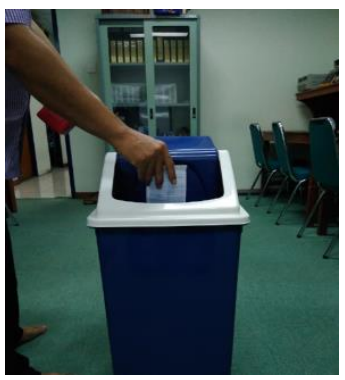

(c)

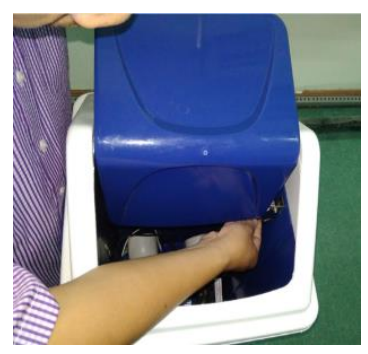

(b)

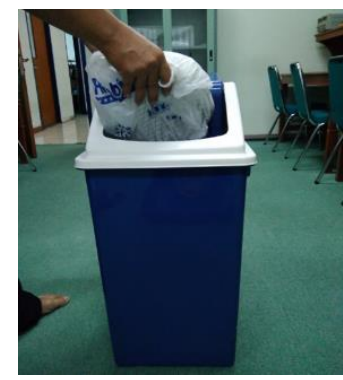

(d)
Gambar 9. (a) perakitan sistem elektronik

(b) emasangan sensor opto proximitry

(c) pengujian pada ukuran benda kecil

(d) pengujian pada sampah ukuran benda besar.

\section{Pengujian Kapasitas Baterai}

Prototipe menggunakan catu daya dari sebuah baterai roda dua sepeda motor dengan kapasitas 12V/6A. Pada saat digunakan power dari baterai akan berkurang seiring dengan waktu penggunaan. Pada Tabel 1 diperlihatkan korelasi tegangan baterai (Volt) dan kapasitas baterai (\%) hasil pengamatan.

Tabel 1. Korelasi tegangan baterai (Volt) dan kapasitas baterai $(\%)$ hasil pengamatan

\begin{tabular}{|c|c|c|}
\hline $\begin{array}{c}\text { Tegangan } \\
\text { Baterai } \\
\text { (Volt) }\end{array}$ & $\begin{array}{c}\text { Tegangan } \\
\text { V_SEN } \\
\text { (Volt) }\end{array}$ & $\begin{array}{c}\text { Kapasitas } \\
\text { Baterai } \\
\%\end{array}$ \\
\hline 12 & 4.24 & 100 \\
\hline 11 & 3.88 & 87.5 \\
\hline 10 & 3.53 & 75.0 \\
\hline 9 & 3.18 & 62.5 \\
\hline 8 & 2.82 & 50.0 \\
\hline
\end{tabular}

Pada saat kapasitas baterai tinggal 50\% mikrokontroler akan segera memberikan logika ' 1 ' pada pin POWER_RLY (Gambar 4 (b)) untuk segera menghidupkan power charging. Bila pada pin PWR_PLUG (Gambar 7) tidak teridentifikasi power plug di SC1, maka 
mikrokontroler akan memberikan notifikasi suara buzzer, menandakan baterai harus segera di-charge.

Pada Gambar 7 IC1 dipasang sebagai power regulator $5 \mathrm{~V}$ untuk seluruh sistem kendali termasuk mikrokontroler. Masukan tegangan dari IC1 berkisar antara $12 \mathrm{~V}$ (Baterai penuh 100\%) sampai 8V (Baterai melemah sampai $50 \%$ ). Formulasi tegangan keluaran dari IC1 adalah sebesar:

$$
\text { Vout }=1.25\left(1+\frac{\mathrm{R} 9+\mathrm{R} 10}{\mathrm{R} 7+\mathrm{R} 8}\right)+\mathrm{I}_{\mathrm{adj}}(\mathrm{R} 9+\mathrm{R} 10)
$$

Vout $=1.25\left(1+\frac{330+390}{120+120}\right)+100 \mathrm{uA} \cdot(330+390)=5 \mathrm{~V}$

Fuse (F1) adalah sebagai pembatas arus. Sistem catu daya sistem dibatasi sampai 1A. Bila sistem overload (short circuit), F1 ini akan putus diiringi dengan matinya lampu LED (LD2).

\section{Pengujian level Suara}

Pengujian level suara adalah salah satu cara untuk menguji seberapa keras tempat sampah bersuara diperdengarkan tanpa menggangu lingkungan disekitarnya pada jarak 3 meter. Jarak 3 meter dipilih karena diinginkan tidak menggangu sekitarnya. Pengujian dilakukan dengan menggunakan sound level meter DS1001. Pengujian dilakukan dulu menggunakan suara manusia seperti yang diperlihatkan pada Tabel 2 berikut:

Tabel 2. Pengukuran suara manusia dengan DS1001

\begin{tabular}{|c|c|c|}
\hline Aksi & $\begin{array}{c}\text { Jarak } \\
(\mathrm{m})\end{array}$ & $\begin{array}{c}\text { Desibel } \\
(\mathrm{dB})\end{array}$ \\
\hline Bisikan & 0.5 & 35 \\
\hline Percakapan & 3 & 60 \\
\hline Tepuk Tangan & 3 & 80 \\
\hline
\end{tabular}

Dari pengujian tersebut dapat disimpulkan bahwa tong sampah bersuara efektif diperdengarkan pada jarak 3 meter adalah antara $60 \mathrm{~dB}$ sampai $70 \mathrm{~dB}$.

\section{Pengujian Jenis Musik}

Pengujian jenis musik adalah salah satu cara untuk menguji responder peduli terhadap tempat sampah bersuara. Beberapa suara diperdengarkan pada jarak 3 meter, dengan beberapa efek yang dimainkan seperti bunyi tiga dimensi (3D) dari: bomb jatuh, helicopter, laju kereta, sirene polisi, peluit, gelas pecah, auman singa dan tangisan bayi. Bunyi-bunyian 3D sangat menarik untuk diperdengarkan, karena antara speaker left (L), speaker right (R), dan speaker sub woffer ketiga-tiganya sangat aktif seperti suara dolby surround sound bioskop. Suara 3D dapat di download secara gratis di beberap situs dengan durasi yang sangatpendek (antara 3 detik- 5 detik).

Dari beberapa permainan suara yang diperdengarkan, dengan variasi suara cenderung berfrekuensi rendah (bass) maupun berfrekuensi tinggi (treble), kemudian diukur level suara ( $\mathrm{dB}$ meter) selanjutnya dianalisa terhadap seberapa jauh perhatian terhadap suara tersebut. Pada Tabel 3 diperlihatkan aksi variasi suara terhadap respon perhatian orang.

Tabel 3. Aksi variasi suara terhadap respon perhatian

\begin{tabular}{|c|c|c|c|c|}
\hline \multirow{2}{*}{ Aksi } & \multirow{2}{*}{$\begin{array}{c}\text { Desibel } \\
\end{array}$} & \multicolumn{2}{|c|}{ Frekuensi Suara } & \multirow{2}{*}{ Respon } \\
\cline { 3 - 4 } & $(\mathrm{dB})$ & Bass & Treble & \\
\hline Bom Jatuh & 70 & $\mathrm{x}$ & & Baik Sekali \\
\hline Helicopter & 60 & $\mathrm{x}$ & $\mathrm{x}$ & Baik \\
\hline Laju Kereta & 75 & & $\mathrm{x}$ & Kurang \\
\hline Sirene Polisi & 80 & & $\mathrm{x}$ & Kurang \\
\hline Peluit & 80 & & $\mathrm{x}$ & Kurang \\
\hline Gelas pecah & 75 & $\mathrm{x}$ & $\mathrm{x}$ & Baik Sekali \\
\hline Auman singa & 70 & $\mathrm{x}$ & & Kurang \\
\hline Tangisan Bayi & 70 & & $\mathrm{x}$ & Baik Sekali \\
\hline
\end{tabular}

Respon terbaik dari pengalihan perhatian adalah pada suara bom jatuh, gelas pecah dan tangisan bayi. Analisanya kemungkinan besar ketiga suara tersebut sangat sensitif terhadap fisikologi manusia.

\section{KESIMPULAN}

Telah berhasil diancang bangun sebuah prototipe tempat sampah elektronik bersuara berbasis ATMega328P dan decoder VS1011. Komunikasi input-output (I/O) berbeda tegangan $5 \mathrm{~V}$ ke $3.3 \mathrm{~V}$ dapat dilakukan dengan menggunakan pembagi tegangan tanpa menggunakan komponen konverter. Konstanta pembagi tegangan adalah $2 / 3$. Tegangan $3.3 \mathrm{~V}$ yang masuk melalui pin input mikrokontroler masih ditolerir pada logika ' 1 ' sesuai dengan taraf tegangan transistor-transistor logic (TTL). 
Optocoupler switch diaplikasikan pada sebuah relay yang berbeda potensial. Pada tegangan logika ' 1 ' mikrokontroler memberikan kontribusi arus sebesar $13.6 \mathrm{~mA}$ (dari $20 \mathrm{~mA}$ ) untuk mengoperasikan sebuah relay dengan tegangan $12 \mathrm{~V}$ dan arus listrik sebesar $118 \mathrm{~mA}$. Optocoupler diaplikasikan selain sebagai voltage ripple reducer juga digunakan sebagai voltage protector.

Kapasitas baterai menurun hingga 50\%, ditunjukan dengan tegangan jepit baterai turun menjadi rata-rata sebesar 8 Volt. Atau melewati pembagi tegangan dengan nilai 2.82 Volt terbaca oleh mikrokontroler.

Prototipe (tempat sampah) diuji pada jarak 3 meter. Pada kekuatan sinyal audio antara 60-70 $\mathrm{dB}$, suara masih dapat diperdengarkan tanpa menggangu aktivitas sekitarnya. Suara yang memiliki nilai fisikologi seperti suara bom, gelas pecah dan tangisan bayi memberikan respon tanggapan yang paling baik.

\section{UCAPAN TERIMA KASIH}

Penelitian ini didukung oleh Prodi Elektro Fakultas Sains dan Teknologi Universitas Al Azhar Indonesia dari Research Grant internal LP2M UAI 2016-2017.

\section{DAFTAR ACUAN/PUSTAKA}

[1] Disney.wikia.com/wiki/Push_the_Talking Trash_Can, (Diakses pada 10 Oktober 2016)

[2] Ergonomic trash Can, www.themarysue.com/savepush, (Diakses pada 05 November 2016)

[3] Music shield V2, wiki.seedstudio.com/wiki/Music_Shield_V 2.0. (Diakses pada 01 November 2016) 